\title{
Time dependent neuroprotection of mycophenolate mofetil: effects on temporal dynamics in glial proliferation, apoptosis, and scar formation
}

\author{
Fahim Ebrahimi, Marco Koch, Philipp Pieroh, Chalid Ghadban, Constance Hobusch, Ingo Bechmann \\ and Faramarz Dehghani
}

\begin{abstract}
Background: Immunosuppressants such as mycophenolate mofetil (MMF) have the capacity to inhibit microglial and astrocytic activation and to reduce the extent of cell death after neuronal injury. This study was designed to determine the effective neuroprotective time frame in which MMF elicits its beneficial effects, by analyzing glial cell proliferation, migration, and apoptosis.
\end{abstract}

Methods: Using organotypic hippocampal slice cultures (OHSCs), temporal dynamics of proliferation and apoptosis after N-methyl-D-aspartate (NMDA)-mediated excitotoxicity were analyzed by quantitative morphometry of Ki-67 or cleaved caspase-3 immunoreactive glial cells. Treatment on NMDA-lesioned OHSCs with mycophenolate mofetil (MMF) $100 \mu \mathrm{g} / \mathrm{mL}$ was started at different time points after injury or performed within specific time frames, and the numbers of propidium iodide (PI) $)^{+}$degenerating neurons and isolectin $(\mathrm{I}) \mathrm{B}_{4}^{+}$microglial cells were determined. Pre-treatment with guanosine $100 \mu \mathrm{mol} / \mathrm{I}$ was performed to counteract MMF-induced effects. The effects of MMF on reactive astrocytic scar formation were investigated in the scratch-wound model of astrocyte monolayers.

Results: Excitotoxic lesion induction led to significant increases in glial proliferation rates between 12 and 36 hours after injury and to increased levels of apoptotic cells between 24 and 72 hours after injury. MMF treatment significantly reduced glial proliferation rates without affecting apoptosis. Continuous MMF treatment potently reduced the extent of neuronal cell demise when started within the first 12 hours after injury. A crucial time-frame of significant neuroprotection was identified between 12 and 36 hours after injury. Pre-treatment with the neuroprotective nucleoside guanosine reversed MMF-induced antiproliferative effects on glial cells. In the scratch-wound model, gap closure was reached within 48 hours in controls, and was potently inhibited by MMF.

Conclusions: Our data indicate that immunosuppression by MMF significantly attenuates the extent of neuronal cell death when administered within a crucial time frame after injury. Moreover, long-lasting immunosuppression, as required after solid-organ transplantation, does not seem to be necessary. Targeting inosine 5-monophosphate dehydrogenase, the rate-limiting enzyme of purine synthesis, is an effective strategy to modulate the temporal dynamics of proliferation and migration of microglia and astrocytes, and thus to reduce the extent of secondary neuronal damage and scar formation.

Keywords: Neuroprotection, Immunosuppression, Organotypic hippocampal slice cultures, Mycophenolate mofetil, Inosine 5-monophosphate dehydrogenase, Excitotoxicity, Apoptosis, Proliferation, Scratch-wound model

\footnotetext{
* Correspondence: Faramarz. Dehghani@medizin.uni-leipzig.de

Institute of Anatomy, Leipzig University, 04103, Leipzig, Germany
} 


\section{Background}

Acute pathologies of the central nervous system (CNS) such as traumatic brain and spinal cord injury, excitotoxicity, or cerebral ischemia cause immediate and irreversible damage to neurons, often associated with severe neurological impairment. All acute lesions trigger pathophysiological cascades that additionally involve delayed loss of primarily unaffected neuronal cell populations, the process known as secondary damage [1-4]. Within the scope of this phenomenon, highly complex and dynamic neuron-glia interactions lead to the activation, proliferation, and recruitment of astrocytes, microglial cells, and blood-borne immune cells. To a certain extent, inflammatory cascades carried by direct cell-cell interactions via contact-dependent communication (such as Ephrin receptors or repulsive guidance molecules) determine the mode and dimension of glial activation, glutamate sensitivity or axonal regrowth [5-8]. Furthermore, the release of a variety of soluble factors from activated glial cells modulates neuronal injury and recovery, as shown for proand anti-inflammatory cytokines, nitric oxide, chemokines, growth factors, prostaglandins, and reactive oxygen species [9-14]. Consequently, neuroinflammatory responses in the aftermath of acute neuropathologies may have detrimental effects, suggesting that an inhibition of glial activation by means of immunosuppression may be beneficial for neuronal survival and recovery [15-17].

Immunosuppressive drugs have been studied with regard to their capacity to arrest secondary injury cascades in a variety of models of acute CNS injury or ischemia. However, the widespread use of steroids such as methylprednisolone as acute pharmacological intervention after spinal-cord injuries has recently been questioned because of reports of only marginal effects on neurological outcome in clinical trials in opposition to the earlier promising experimental evidence [18-20]. Other immunosuppressant agents such as the immunophilin ligands ciclosporin A and FK506 (tacrolimus) likewise produced improvement neuronal survival and axonal regeneration, and have been widely investigated in animal models of acute CNS injury or ischemia [16,21-24].

The immunosuppressant mycophenolate mofetil (MMF) is clinically established for prevention of allograft rejection after solid-organ transplantation [25]. After administration, the morpholino-ester pro-drug is immediately hydrolyzed to the active compound mycophenolic acid, which in turn is a selective and reversible inhibitor of inosine 5-monophosphate dehydrogenase (IMPDH), the rate-limiting enzyme of the de novo purine-synthesis pathway [26-28]. The non-competitive inhibition is fivefold more potent with the type II isoform of IMPDH (IMPDH2), which is preferentially upregulated in activated leucocytes, whereas isoform I is constitutively expressed in most cell types, resulting in an almost specific inhibition of proliferation in activated leucocytes [29].

We have previously shown that MMF exerts a potent neuroprotective activity on excitotoxically lesioned organotypic hippocampal slice cultures (OHSCs) and inhibits microglial and astrocytic proliferation when administered concomitantly with lesion induction [30]. In addition, MMF effectively suppresses lipopolysaccharide (LPS)-stimulated microglial and astrocytic activation and consecutive secretion of pro-inflammatory mediators [31] by inhibition of enzymatic activity of inducible nitric oxide synthase, among other effects [32]. Furthermore, treatment with mycophenolate mofetil strongly improves the preservation of myelinated long-range projections in vitro [33] and axonal regeneration in vivo [34].

These promising studies raise the possibility that immediate MMF administration might be useful for the treatment of acute CNS lesions. However, little is known about the effective time-frame in which MMF treatment can still be applied without inducing widespread immunosuppression.

Thus, we assessed the effects of MMF on the temporal dynamics of microglial and astrocytic proliferation and apoptosis after acute excitotoxicity in OHSCs, and analyzed MMF-mediated effects on scar formation in the scratch-wound model.

\section{Methods}

All animal experiments were performed in accordance with the Policy on Ethics and the Policy on the Use of Animals in Neuroscience Research as approved by the directive 2010/63/EU of the European Parliament and of the Council of the European Union on the protection of animals used for scientific purposes.

\section{Preparation and maintenance of organotypic hippocampal slice cultures}

For the preparation of OHSCs, 8-day-old Sprague-Dawley rats were decapitated, and the brains were dissected under sterile conditions according to standard protocols [35]. After removal of the frontal pole and the cerebellum, the brains were placed in preparation medium at $4^{\circ} \mathrm{C}$; this preparation medium consisted of minimal essential medium (MEM; Gibco BRL Life Technologies, Eggenstein, Germany) pH 7.35 including 1\%v/v glutamine (Gibco). Subsequently, these preparations were sliced into sections $350 \mu \mathrm{m}$ thick on a vibratome (Vibratom VT $1200 \mathrm{~S}$; Leica Microsystems AG, Wetzlar, Germany). Approximately six to eight OHSCs were obtained from each brain, and were immediately transferred into cell- culture inserts with a pore size of $0.4 \mu \mathrm{m}$ (Falcon, BD Bioscience Discovery Labware, Bedford, MA, USA), which were placed in six-well culture dishes (Falcon) and fed with $1 \mathrm{ml}$ culture medium per well. The culture medium consisted of $50 \% \mathrm{v} / \mathrm{v}$ MEM, 
$25 \% \mathrm{v} / \mathrm{v}$ Hanks' balanced salt solution supplemented with $185 \mathrm{mg} / \mathrm{L} \mathrm{CaCl} 2$ and $100 \mathrm{mg} / \mathrm{L} \mathrm{MgCl}_{2}, 25 \% \mathrm{v} / \mathrm{v}$ normal horse serum (all Gibco), 2\% v/v glutamine, $1 \mu \mathrm{g} / \mathrm{ml}$ insulin (Boehringer, Mannheim, Germany), $1.2 \mathrm{mg} / \mathrm{ml}$ glucose (Braun, Melsungen, Germany), $0.1 \mathrm{mg} / \mathrm{ml}$ streptomycin, $100 \mathrm{U} / \mathrm{ml}$ penicillin and $0.8 \mu \mathrm{g} / \mathrm{ml}$ vitamin C (SigmaAldrich Chemicals, Deisenhofen, Germany) at $\mathrm{pH}$ 7.4. The culture dishes were incubated for 6 days at $35^{\circ} \mathrm{C}$ in a fully humidified atmosphere with $5 \% \mathrm{CO}_{2}$ and the culture medium was changed on alternate days. Mycophenolate mofetil (CellCept; Roche, Grenzach-Wyhlen, Germany) was diluted in cell-culture medium for application to OHSCs at a previously determined effective concentration of $100 \mu \mathrm{g} / \mathrm{ml}$ [30]. The nucleoside guanosine (SigmaAldrich Chemicals) was applied at a concentration of $100 \mu \mathrm{mol} / \mathrm{l}$ at 6 days in vitro before MMF treatment to counteract MMF-induced purine depletion.

\section{Treatment protocols of organotypic hippocampal slice cultures}

The preparations were randomly divided into different experimental groups and treated according to the following protocols:

\section{Control}

Unlesioned OHSCs $(\mathrm{n}=57)$ served as control slices, and were kept in culture medium for 9 days in vitro without any treatment.

\section{NMDA}

At 6 days in vitro, OHSCs $(\mathrm{n}=43)$ were lesioned with NMDA $(50 \mu \mathrm{mol} / \mathrm{l}$; Sigma-Aldrich Chemicals) for 4 hours, and thereafter kept in culture medium for another 3 days in vitro.

\section{NMDA time series}

At 6 days in vitro, OHSCs were lesioned with NMDA for 4 hours, and subsequently fixed at 12, 24, 36, 48 or 72 hours after lesion induction (Figure $1 \mathrm{~A}$ ).

\section{Continuous MMF treatment after injury}

OHSCs were kept in culture medium for 6 days in vitro, lesioned with NMDA $(50 \mu \mathrm{mol} / \mathrm{l})$ for 4 hours, and treated with MMF $100 \mu \mathrm{g} / \mathrm{ml}$ at different starting time points after injury ( 4 hours, $\mathrm{n}=17 ; 8$ hours, $\mathrm{n}=20 ; 12$ hours, $\mathrm{n}=24 ; 16$ hours, $\mathrm{n}=15 ; 24$ hours, $\mathrm{n}=18 ; 36$ hours, $\mathrm{n}=16 ; 48$ hours, $\mathrm{n}=17$ ) for another 3 days in vitro, (Figure $2 \mathrm{~A}$ ).

\section{Time frame of MMF treatment after injury}

OHSCs were kept in culture medium for 6 days in vitro, lesioned with NMDA $(50 \mu \mathrm{mol} / \mathrm{l})$ for 4 hours and thereafter treated with MMF $(100 \mu \mathrm{g} / \mathrm{ml})$ within a certain time window (i) 4 to 8 hours after injury $(n=21)$, (ii) 4 to 24 hours after injury $(\mathrm{n}=26)$, (iii) 4 to 48 hours after injury ( $\mathrm{n}=15)$, (iv) $12-36$ hours after injury $(\mathrm{n}=23)$ and (v) 24 to 48 hours after injury $(\mathrm{n}=15)$, (Figure $3 \mathrm{~A})$.

\section{Determination of neuronal cell death and confocal laser scanning microscopy}

To visualize the pyknotic nuclei of degenerating neurons, OHSCs at 9 days in vitro were incubated with PI $5 \mu \mathrm{g} / \mathrm{ml}$ (Chemicon, Nuernberg, Germany) for 2 hours before fixation. The use of PI as an indicator for cell viability and for identification of degenerating neurons in OHSCs has been established previously [36,37]. After rinsing with $0.1 \mathrm{~mol} / \mathrm{l}$ phosphate buffer, slices were fixed with a $4 \% \mathrm{w} / \mathrm{v}$ solution of paraformaldehyde in $0.2 \mathrm{~mol} / \mathrm{l}$ phosphate buffer overnight.

The pre-fixed OHSCs were then removed from the cell culture inserts, placed into 24-well plates (Falcon), and washed for 10 minutes with PBS containing $0.03 \% \mathrm{v} / \mathrm{v}$ Triton X-100 (PBS/Triton X-100) for 10 minute. The slices were then incubated with normal goat serum (diluted 1:20 in PBS/Triton X-100) for 1 hours, and stained with fluorescein isothiocyanate (FITC)-conjugated Griffonia simplicifolia $\mathrm{IB}_{4}$ (Vector laboratories, Burlingame, CA, USA) diluted 1:50 in PBS/Triton X-100 containing 0.25\% (w/v) bovine serum albumin for 3 hours. The slices were washed with PBS/Triton X-100 for 10 minute and finally mounted under coverslips using fluorescent mounting medium (Dako Diagnostika GmbH, Hamburg, Germany).

OHSCs were analyzed and imaged with a confocal laser scanning microscope (LSM 510 Meta, Zeiss, Goettingen, Germany). For detection of $\mathrm{PI}^{+}$nuclei of degenerating neurons, monochromatic light at $543 \mathrm{~nm}$ and an emission bandpass filter of 585 to $615 \mathrm{~nm}$ were used. For visualization of $\mathrm{IB}_{4}^{+}$microglial cells, monochromatic light at $488 \mathrm{~nm}$ with a dichroic beam splitter (FT 488/543) and an emission band-pass filter of 505 to $530 \mathrm{~nm}$ were used.

Confocal images were obtained at 160-fold magnification at a resolution of $1024 \times 1024$ pixels. Using the mid-stag mode and the Z-mode of the confocal microscope, the optical mid-stag and the two adjacent optical sections $(2 \mu \mathrm{m}$ thick) of the granule cell layer (GCL) in the dentate gyrus (DG) were obtained and converted into a binary image. Subsequently, numbers of $\mathrm{IB}_{4}^{+}$microglial cells and $\mathrm{PI}^{+}$degenerating neurons were counted in the GCL of the DG (cells/GCL) as previously described [14,37,38]. Lesioned OHSCs treated with MMF at different time points or within specific time frames after injury were compared with OHSCs treated with NMDA alone.

\section{Analyses of microglial and astrocytic proliferation and apoptosis}

For analyses of proliferation and apoptosis indices of microglial cells and astrocytes, NMDA-lesioned OHSCs were fixed at 12, 24, 36, 48 and 72 hours after injury. 

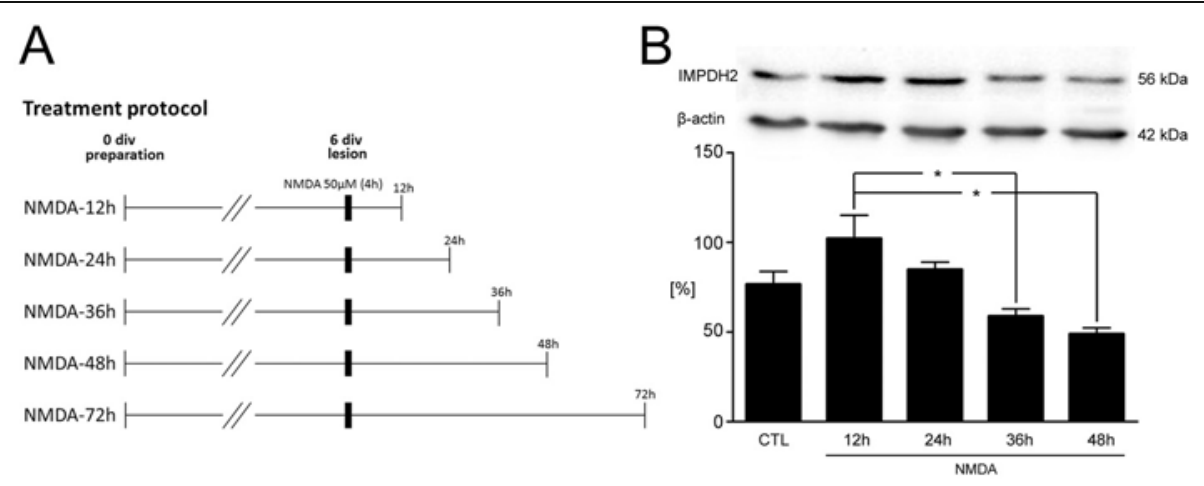

\section{C}
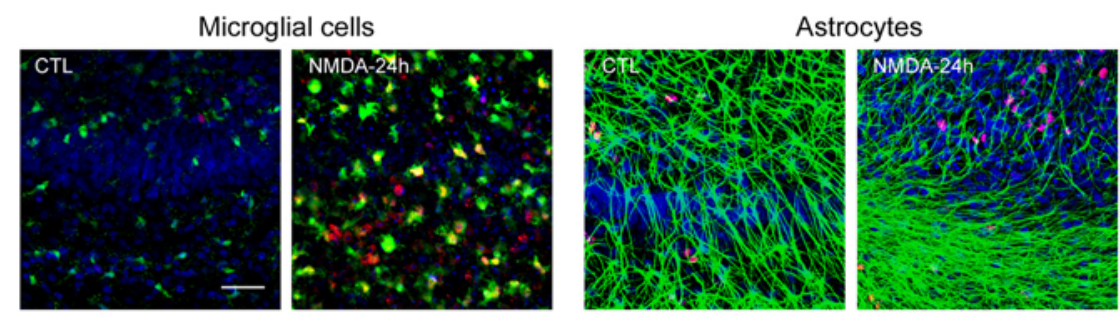

D

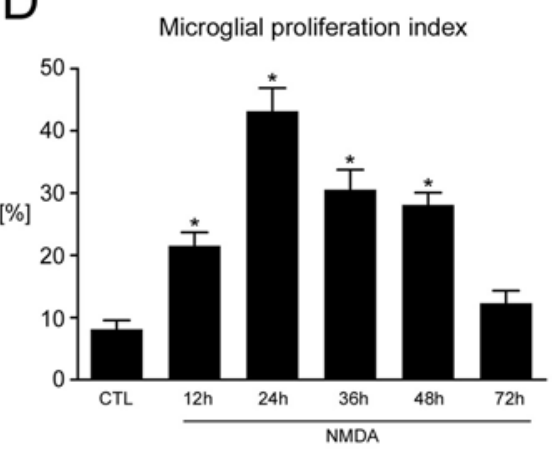

$\mathrm{E}$
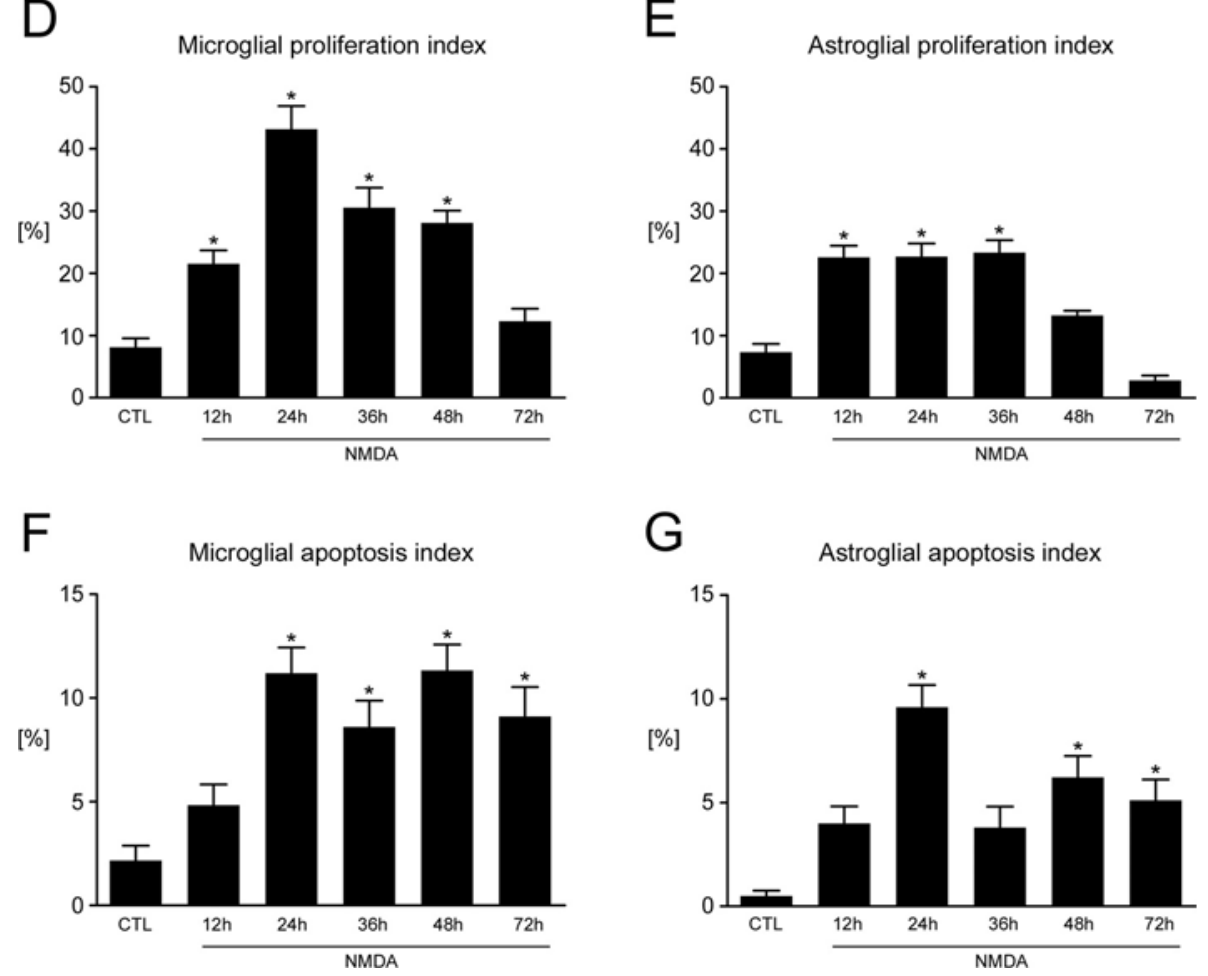

Figure 1 Temporal dynamics of cellular responses after excitotoxic lesion. (A) Treatment protocols. (B) (Upper panel) Immunoblot analyses of inosine 5-monophosphate dehydrogenase (IMPDH)2 and $\beta$-actin at different time points post-lesion. $N$-methyl-D-aspartate (NMDA) lesion affected IMPDH2 immunoreactivity over time. (Lower panel) Semiquantitative analyses of immunoblot data $(n=4)$ showed a significant reduction in the amount of IMPDH2 at 36 and 48 hours after injury compared with the values at 12 hours $\left({ }^{*} P<0.05\right)$. (C) Confocal laser scanning microscopy images, double-labeled with isolectin (I)B $B_{4}$ (microglial cells, green) or glial fibrillary acidic protein (GFAP) (astrocytes, green) each in combination with Ki-67 (proliferating cells, red). Temporal patterns of (D) microglial and (E) astroglial proliferation indices after NMDA-mediated excitotoxic lesion as shown by quantitative morphometry of $\mathrm{Ki}-67^{+}$glial cell ratios $\left({ }^{*} P<0.05\right.$ vs. control $\left.(C T L)\right)$. Microglial proliferation indices were significantly increased from 12 hours to 48 hours, with maximum values at 24 hours post-lesion. Astrocytic proliferation indices were significantly increased from 12 hours to 36 hours after injury. (F-G) Microglial and astroglial apoptosis indices after NMDA-mediated excitotoxic lesion as measured by assessment of ratios of cleaved caspase- 3 immunoreactive glial cells $\left({ }^{*} P<0.05 \mathrm{vs}\right.$. control $(\mathrm{CTL})$ ). The apoptosis indices of both microglial cells and astrocytes were significantly increased between 24 and 72 hours, with a decline at 36 hours post-lesion. Scale bar $=50 \mu \mathrm{m}$. 


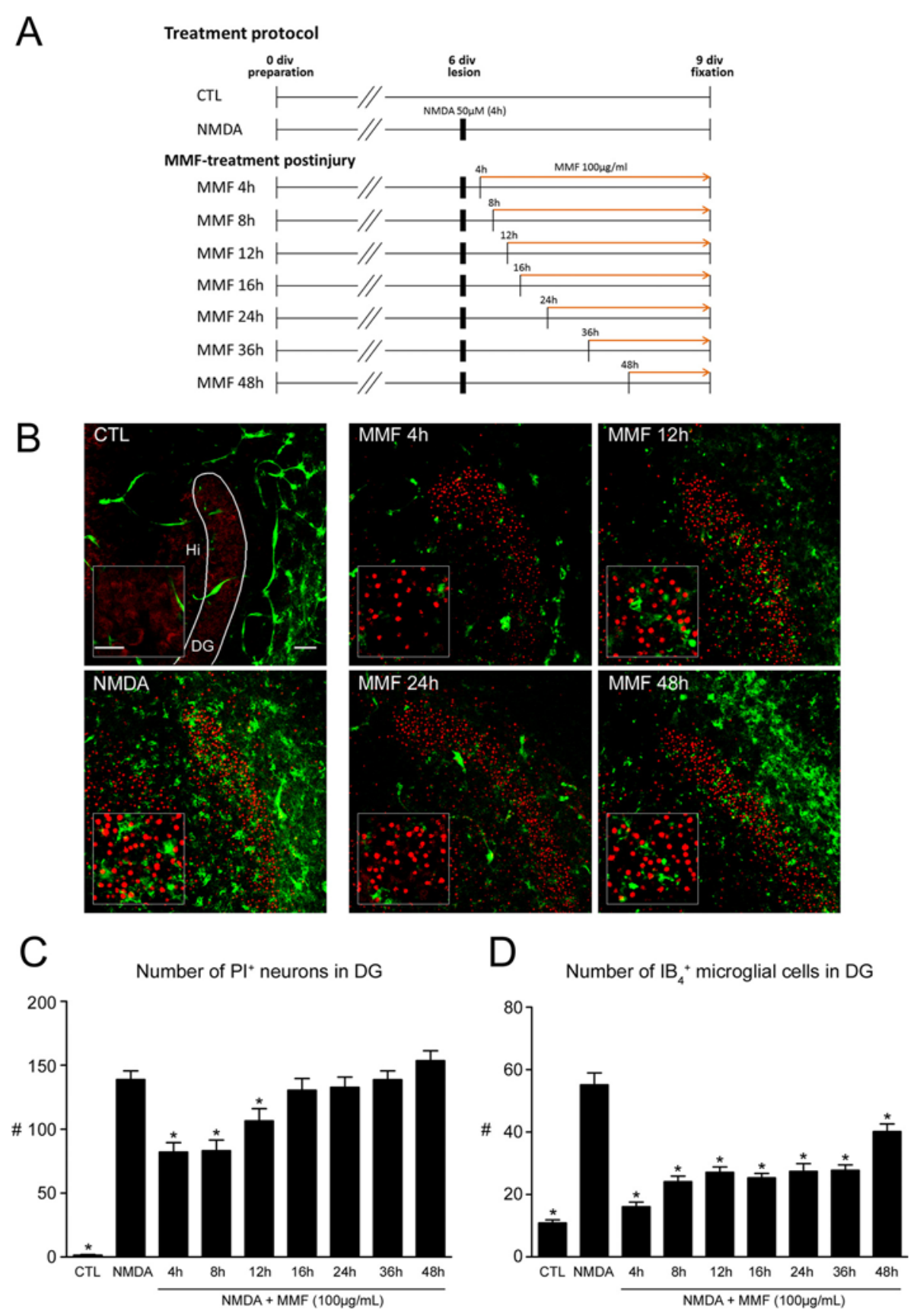

Figure 2 Effects of continuous mycophenolate mofetil (MMF) treatment from different time points after injury on neuronal survival and microglial activation in organotypic hippocampal slice cultures (OHSCs). (A) Treatment protocols. (B) Confocal laser scanning microscopy images in overview and higher magnification, double-labeled with propidium iodide (PI) (degenerating neurons, red) and $\mathrm{B}_{4}$ (microglial cells, green). Untreated control (CTL) OHSCs had very good preservation of the hippocampal formation with almost no $\mathrm{Pl}^{+}$pyknotic nuclei and only a few ramified $\mathrm{IB}_{4}^{+}$microglial cells. Slices treated with NMDA $50 \mu \mathrm{mol} / \mathrm{I}$ for 4 hours had massive accumulation of amoeboid IB ${ }_{4}^{+}$ microglial cells and a dramatic increase in $\mathrm{PI}^{+}$neuronal nuclei. Delayed treatment (until 12 hours after injury) with MMF resulted in a significant reduction of $\mathrm{Pl}^{+}$degenerating neurons. Numbers of microglial cells were reduced even with late administration of MMF (after 48 hours post-injury). (C-D) Quantitative analyses of the effects of MMF on NMDA-lesioned OHSCs. The mean numbers of (C) $\mathrm{PI}^{+}$degenerating neurons and (D) $\mathrm{IB}_{4}^{+}$microglial cells were calculated for each experimental group and compared with OHSCs treated with NMDA alone $\left(^{*} P<0.05\right.$ vs. NMDA). DG, dentate gyrus; Hi, hilus. Scale bars $=50 \mu \mathrm{m}$ in overviews; $20 \mu \mathrm{m}$ in insets. 


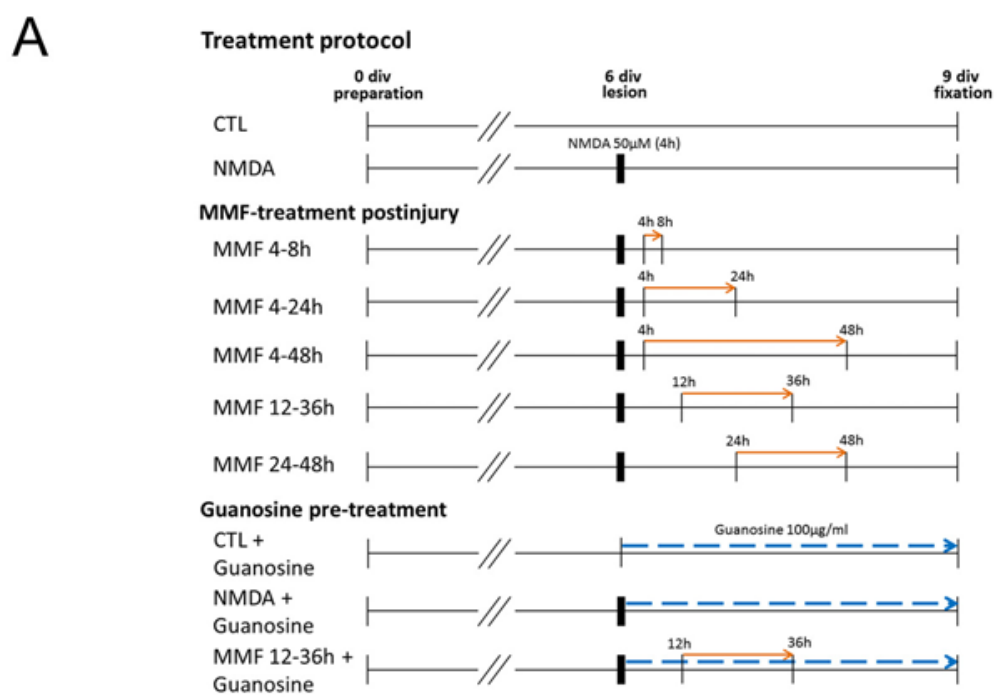

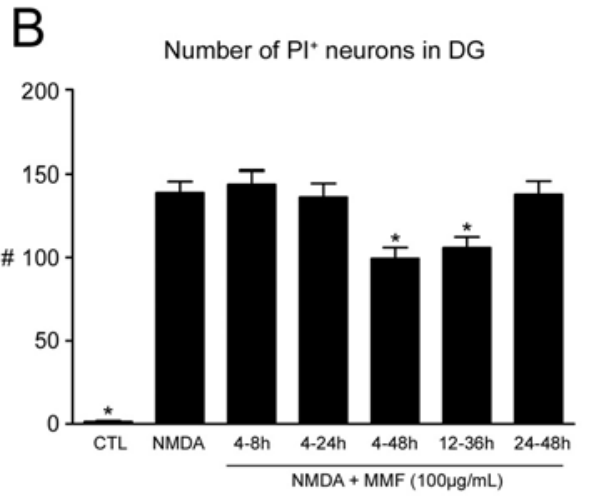

Number of $\mathrm{PI}^{+}$neurons in DG

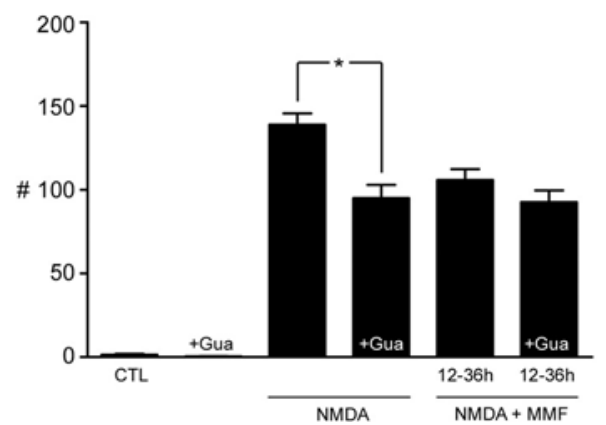

C

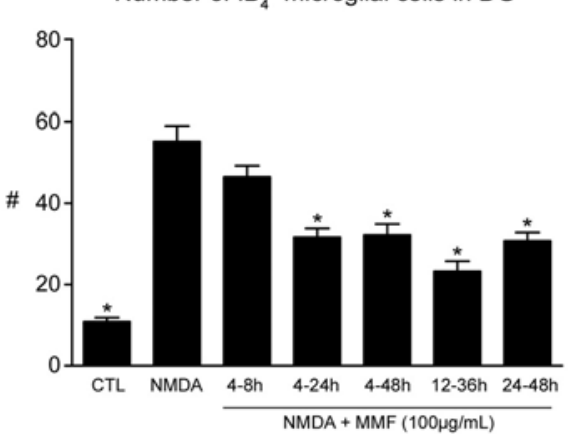

$\mathrm{E}$

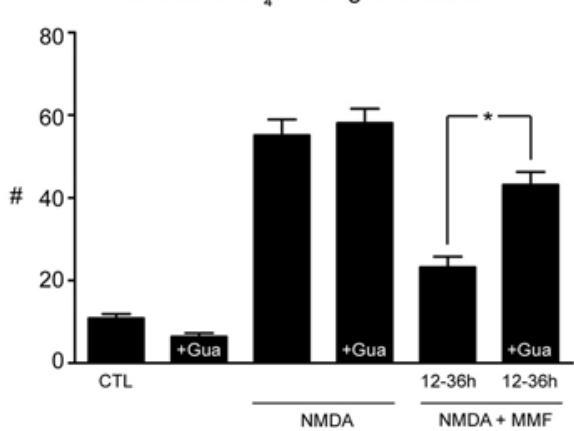

Figure 3 Mycophenolate mofetil (MMF) treatment in specific time frames after injury and effects of guanosine on neuroprotective and antiproliferative properties of MMF. (A) Treatment protocols. (B,C) Quantitative analyses of the effects of short-term MMF treatment (100 $\mu \mathrm{g} /$ $\mathrm{ml}$ ) on neuronal survival and microglial activation in organotypic hippocampal slice cultures (OHSCs) when MMF was administered in different time windows after injury. Mean numbers of (B) propidium iodide (PI) ${ }^{+}$degenerating neurons and $(\mathbf{C}) \mathrm{B}_{4}^{+}$microglial cells were calculated for each experimental group, and compared with OHSCs treated with $N$-methyl-D-aspartate (NMDA) alone $\left({ }^{*} P<0.05\right.$ vs. NMDA). MMF elicits strong neuroprotective effects when administered within the time frame of 4 to 48 hours or even 12 to 36 hours after injury. However, treatment within 4 to 24 hours or 24 to 48 hours after injury likewise reduced numbers of $\mathbf{I B}_{4}^{+}$microglial cells. (D,E) Quantitative analyses of guanosine effects. Mean numbers of (D) $\mathrm{Pl}^{+}$degenerating neurons and $(\mathbf{E}) \mathrm{IB}_{4}^{+}$microglial cells were calculated for each experimental group and compared with matched OHSCs that did not receive guanosine $\left({ }^{*} P<0.05\right)$. Guanosine did not affect either neuronal viability or microglial activation when applied to unlesioned control (CTL) OHSCs. In NMDA-lesioned OHSCs subjected to guanosine treatment, there was a significant reduction in the numbers of $\mathrm{Pl}^{+}$degenerating neurons, whereas the numbers of $\mathrm{IB}_{4}^{+}$microglial cells were unaffected. However, application of guanosine to OHSCs that received MMF treatment within the 12 to 36 hour time window significantly reversed the antiproliferative reduction in IB microglial cells without affecting MMF-dependent neuroprotection. 
Quadruple staining was performed using GFAP, $\mathrm{IB}_{4}$, 4'-6-diamidino-2-phenlyindole (DAPI) and Ki-67 or cleaved caspase-3, respectively. OHSCs were removed from the cell-culture insert membranes, washed with PBS, and cryoprotected with ascending solutions of $10 \%$, $20 \%$ and $30 \% \mathrm{w} / \mathrm{v}$ sucrose before being sectioned horizontally at $12 \mu \mathrm{m}$ thickness on a cryostat (CM3050 S; Leica) at $-23^{\circ} \mathrm{C}$. Obtained sections were subsequently mounted on microscope slides (Superfrost Plus; Gerhard Menzel GmbH, Braunschweig, Germany) and air-dried. Cryostat sections were washed with PBS/Triton X-100 for 10 minutes, pre-incubated with normal goat serum (diluted 1:20 in PBS/Triton) for 30 minutes and incubated with the primary antibody (rabbit anti- Ki-67, diluted 1:200; DCS Innovative Diagnostik Systeme, Hamburg, Germany) or (rabbit anti-cleaved caspase-3, diluted 1:200; Cell Signalling Technology, Danvers, MA, USA) for 12 hours. After washing with PBS-Triton X100 , the slices were simultaneously incubated with the secondary antibody (1:200, Alexa 568-conjugated goat anti-rabbit IgG; Invitrogen) for 1 hour. Sections were then incubated with a monoclonal rat anti-GFAP antibody (1:200, Dako) for 12 hours, washed, and incubated with the secondary goat anti-rat Alexa 633-conjugated antibody (1:200, Invitrogen) for 1 hour. Microglial cells were stained with $\mathrm{FITC}-\mathrm{IB}_{4}$ for 1 hour as described above. Finally, nuclear staining was performed by application of DAPI $100 \mathrm{ng} / \mathrm{mL}$ (Molecular Probes, Mobitec, Goettingen, Germany) for 15 minutes.

Sections were then washed with PBS-Triton and distilled water for 10 minutes each, coverslipped with fluorescent mounting medium (Dako) and analyzed by confocal laser scanning microscopy in multi-tracking mode. Monochromatic light at 488, 543, and $633 \mathrm{~nm}$ with a dichroic beam splitter (FT UV/488/543/633) was used to visualize cellular nuclei (DAPI; excitation $405 \mathrm{~nm}$, emission band-pass filter 420 to $480 \mathrm{~nm}$ ), microglial cells (FITC-IB 4 ; excitation $488 \mathrm{~nm}$, emission band-pass filter 505 to $530 \mathrm{~nm}$ ), astrocytes (GFAP; excitation $633 \mathrm{~nm}$, emission long pass $650 \mathrm{~nm}$ ), proliferating cells (Ki-67; excitation $543 \mathrm{~nm}$, emission band-pass filter 585 to $615 \mathrm{~nm})$ or cleaved caspase- $3^{+}$immunoreactive cells (cleaved caspase-3; excitation $543 \mathrm{~nm}$, emission band-pass filter 585 to $615 \mathrm{~nm}$ ).

\section{Quantitative morphometry of organotypic hippocampal slice cultures}

Quantitative morphometry was used for determination of the following parameters: 1) the number of $\mathrm{PI}^{+}$degenerating neurons, 2) the number of $\mathrm{IB}_{4}^{+}$microglial cells, 3 ) the number of $\mathrm{Ki}-67^{+}$proliferating cells and 4) the numbers of cleaved caspase- $3^{+}$immunopositive cells each throughout the entire granule-cell layer of the DG using ImageJ software (ImageJ 1.44p, National Institutes of
Health, USA). Proliferation indices were calculated as the percentage of $\mathrm{Ki}-67^{+}$proliferating microglial cells or astrocytes related to the total number of respective glial cells in DG. Correspondingly, apoptosis indices were determined as the percentage of cleaved caspase $-3^{+}$ immunopositive glial cells per total numbers of glial cells.

\section{Immunoblotting and semiquantitative analyses}

For immunochemical analyses, hippocampal formations of differentially treated OHSCs were used. Protein concentrations were determined by the dye-based method of Bradford [39], and equivalent quantities were loaded onto $12.5 \%$ SDS-PAGE gels. After gel electrophoresis, the proteins were blotted onto nitrocellulose membranes, which were then pre-incubated in blocking buffer (5\% milk, $25 \mathrm{mmol} / \mathrm{l}$ Tris- $\mathrm{HCl}, 150 \mathrm{mmol} / \mathrm{l} \mathrm{NaCl}$ ) $\mathrm{pH} 7.5$ to reduce non-specific binding of the antibody. The nitrocellulose membranes were incubated overnight with the aforementioned antibody against IMPDH2 (diluted 1:2000 in blocking buffer containing 0.2\% Tween 20). Binding of the primary antibody was visualized using horseradish peroxidase-conjugated goat antirabbit IgG and enhanced chemiluminescence (Thermo Fisher Scientific, Barrington, IL, USA). For semiquantitative analysis, the relative signal intensities of the immunoreactive bands were determined and standardized as quotients of IMPDH2 intensity units per $\beta$-actin intensity units.

\section{Primary astrocyte cell cultures and scratch-wound model analyses}

Astrocyte cell cultures were prepared from p0-2 Sprague-Dawley rat brains according to standard protocols [40]. In brief, brains were treated with trypsin $(4 \mathrm{mg} / \mathrm{mL}$; Boehringer) in Hank's balanced salt solution without $\mathrm{Ca}^{2+}$ or $\mathrm{Mg}^{2+}$ with DNAse $(0.5 \mathrm{mg} / \mathrm{mL}$; Worthington, Bedford, MA, USA), and resuspended in $1 \mathrm{~mL}$ culture medium, consisting of DMEM (Gibco), supplemented with 10\% FCS (Gibco), 1\% glutamine (Boehringer), 100 $\mathrm{U} / \mathrm{mL}$ penicillin and $0.1 \mathrm{mg} / \mathrm{mL}$ streptomycin (SigmaAldrich Chemicals). The cell suspension was transferred into tissue culture flasks $\left(75 \mathrm{~cm}^{2}\right.$; Falcon) and incubated for 7 days in vitro. Astrocytic monolayers were subsequently treated with trypsin in PBS without $\mathrm{Ca}^{2+}$ or $\mathrm{Mg}^{2+}$, and seeded onto poly- $L$-lysine coated coverslips in 24-well tissue culture plates (Falcon). Purity of astrocytic cultures was verified by immunocytochemistry against GFAP $\left(\right.$ GFAP $^{+}$astrocytes $>98 \%$ ).

For in vitro scratch-wound model experiments, confluent astrocyte monolayers were wounded by scratching with sterile plastic pipette tips. Scratched cultures remained either untreated (control) or were treated with MMF at a concentration of $1 \mu \mathrm{g} / \mathrm{mL}$. At $0,2,6,12,24$ 
and 48 hours after scratching, astrocytes were fixed for assays on cell proliferation, using anti-GFAP and antiKi-67 immunofluorescence staining as described above. Proliferation indices were calculated as the percentage of $\mathrm{Ki}-67^{+}$proliferating astrocytes related to the total number of astrocytes around the scratch-wound area. The mean astrocytic gap widths were measured by image analysis. The mean gap width of untreated (control) cultures at baseline (immediately after scratching; 0 hours) was defined as $100 \%$. Data from other time points and MMF treatment were presented as percentages of the controls at baseline.

\section{Statistical analysis}

Data are presented as mean \pm SEM. For statistical analysis the one-way ANOVA test was used followed by Dunnett's post hoc test or Bonferoni's test for multiple comparisons when the effect of MMF treatment on numbers of $\mathrm{PI}^{+}$degenerating neurons, $\mathrm{IB}_{4}^{+}$microglial cells, Ki- $67^{+}$proliferating cells, cleaved caspase-3positive cells, IMPDH signal intensities or gap widths, respectively, was significant. $P<0.05$ was considered significant.

\section{Results}

Temporal dynamics of proliferation and apoptosis after acute excitotoxic injury

To investigate temporal patterns of glial cell proliferation and apoptosis, indices of Ki-67 and cleaved caspase3 immunoreactive astrocytes and microglial cells were assessed at different proximate time points after the onset of acute excitotoxic lesion.

Unlesioned control OHSCs displayed low levels of Ki$67^{+}$proliferating microglial cells or astrocytes $(8.1 \%$ and $7.3 \%$, respectively) (Figure 1D,E). Correspondingly, apoptosis indices of control OHSCs were markedly low: only $2.2 \%$ microglial cells and $0.5 \%$ astrocytes were immunoreactive for cleaved caspase-3 (Figure 1F,G). After NMDA-mediated excitotoxic lesion induction of OHSCs, the fraction of proliferating microglial cells rapidly increased within the first 12 hours post-lesion, and the proliferation index reached its maximum at 24 hours after injury (12 hours: $21.5 \%, P<0.01 ; 24$ hours: $43.2 \%$, $P<0.0001$ ) (Figure $1 \mathrm{D}$ ). Thereafter the fraction of proliferating microglial cells decreased from $31.7 \%$ at 36 hours to $28.1 \%$ at 48 hours after injury $(P<0.001)$ and reached almost control levels at 72 hours after injury $(11.2 \% \mathrm{Ki}$ $67^{+}$microglial cells, $P>0.05$ ) (Figure 1D). Similarly, astroglial proliferation indices increased most rapidly within the first 12 hours post-lesion and reached a plateau up to 36 hours (12 hours: $22.8 \%$; 24 hours: $22.7 \%$; 36 hours: $23.3 \%, P<0.001$ ), and thereafter fractions of proliferating astrocytes steadily declined (48 hours: 13.3\%; 72 hours: $2.8 \%, P>0.05$ ) (Figure $1 \mathrm{E}$ ).
In the aftermath of NMDA-induced excitotoxic injury, the ratios of glial cells undergoing apoptotic conditions increased steadily over time. At 12 hours post-lesion, the microglial apoptosis indices remained unaltered compared with unlesioned control OHSCs, but the ratio significantly increased within 24 hours and continued to increase until 72 hours after the initial lesion (12 hours: 4.8\%, $P>0.05$; 24 hours: $11.2 \%, P<0.0001 ; 36$ hours: 8.6\%, $P<0.01 ; 48$ hours: $11.3 \%, P<0.0001 ; 72$ hours: 9.1\%, $P<0.001$ ) (Figure 1F). The apoptosis indices of astrocytes were similar to those seen with microglial cells, but with significantly diminished apoptosis ratio at 36 hours post-lesion (12 hours: 4.0\%, $P>0.05$; 24 hours: 9.6\%, $P<0.0001 ; 36$ hours: $3.8 \%, P>0.05 ; 48$ hours: 6.2\%, $P<0.001$; 72 hours: $5.1 \%, P<0.01$ ) (Figure 1G).

\section{Inosine 5-monophosphate dehydrogenase 2} immunoreactivity after $\mathrm{N}$-methyl-D-aspartate-induced lesion and mycophenolate mofetil treatment

IMPDH2 immunoreactivity was assessed in immunoblots at different time points after NMDA-mediated lesion induction of OHSCs at 6 days in vitro. The antibody against IMPDH2 labeled a single band of $56 \mathrm{kDa}$, corresponding to the known molecular weight of the enzyme. This band was found in unlesioned control OHSCs and its intensity gradually changed after NMDA application when assessed at 12, 24, 36 and 48 hours post-lesion. IMPDH2 signal intensity standardized to $\beta$-actin was significantly increased at 12 hours postlesion compared with intensities at 36 and 48 hours after injury $(P<0.05)$ (Figure 1B).

\section{Continuous mycophenolate mofetil treatment of $\mathrm{N}$ - methyl-D-aspartate-lesioned organotypic hippocampal slice cultures from different time points}

In control OHSCs, the typical hippocampal cytoarchitecture was well preserved (Figure 2B). Throughout all optical sections almost no pyknotic $\mathrm{PI}^{+}$-nuclei and only a few $\mathrm{IB}_{4}^{+}$microglial cells were found (control: $1.5 \mathrm{PI}^{+}$and $10.8 \mathrm{IB}_{4}^{+}$cells/GCL) (Figure 2C,D) confirming excellent preservation after 9 days in vitro under standard incubation conditions. Microglial cells, which were primarily found in the molecular and plexiform layers of the DG and hippocampus, exhibited a ramified phenotype with highly branched processes.

OHSCs treated after 6 days in vitro for 4 hours with $50 \mu \mathrm{mol} / \mathrm{l} \mathrm{NMDA}$ and analyzed after 9 days in vitro showed massive neuronal damage, reflected by greatly increased numbers of $\mathrm{PI}^{+}$degenerating neurons exhibiting luminously stained condensed nuclei with occasional signs of karyorrhexis in the GCL of the DG (Figure 2B). Quantitative analysis of $\mathrm{IB}_{4}^{+}$microglial cells confirmed that the number of microglial cells was likewise significantly increased 
compared with controls (NMDA: $138.9 \mathrm{PI}^{+}$and $55.1 \mathrm{IB}_{4}^{+}$ cells/GCL, $P<0.001$ ) (Figure 2C,D).

Continuous treatment of lesioned OHSCs with MMF $100 \mu \mathrm{g} / \mathrm{ml}$ significantly reduced the numbers of both $\mathrm{PI}^{+}$ degenerating neurons and of $\mathrm{IB}_{4}^{+}$microglial cells in a time-dependent manner (Figure 2C,D). When MMF treatment was started at 4 hours after injury, the number of $\mathrm{PI}^{+}$pyknotic nuclei of degenerating neurons was significantly decreased (4 hours: 82.1/GCL, $P<0.001$ ) (Figure 2B,C) compared with NMDA-lesioned cultures only (NMDA: $138.9 / \mathrm{GCL}$ ). The mean number of $\mathrm{IB}_{4}^{+}$ microglial cells correspondingly decreased significantly, dropping from 55.1 cells/GCL to 16.1 cells/GCL $(P<0.001)$ (Figure 2D). Similar neuroprotective effects of MMF were seen when treatment was implemented at 8 hours after injury, which were paralleled by a significant reduction in the number of microglial cells $(8$ hours: $83.2 \mathrm{PI}^{+}$cells/GCL, 24.1 $\mathrm{IB}_{4}^{+}$cells/GCL, $P<0.001$ ) (Figure $2 \mathrm{C}, \mathrm{D}$ ). MMF administration from 12 hours postlesion still resulted in significant neuroprotection (12 hours: 106.5 $\mathrm{PI}^{+}$cells/GCL, $P<0.01$ ) (Figure $2 \mathrm{C}$ ), but the reduction in the mean number of $\mathrm{PI}^{+}$cells was less pronounced compared with the experimental groups that received MMF earlier. Application of MMF at 12 hours after injury caused a similar reduction in numbers of microglial cells compared with an application after 4 or 8 hours (12 hours: $27.1 \mathrm{IB}_{4}^{+}$cells/GCL, $P<0.001$ ) (Figure 2D). However, when MMF treatment was delayed until 16 hours after excitotoxic injury, the neuroprotective effects were no longer visible, and teh numbers of $\mathrm{PI}^{+}$degenerating neurons in the GCL of DG (16 hours: $125.6 \mathrm{PI}^{+}$cells/GCL, $P>0.05$ ) (Figure $2 \mathrm{C}$ ) were now equivalent to those in OHSCs treated with NMDA alone, whereas the number of microglial cells was still considerably decreased (16 hours: $25.3 \mathrm{IB}_{4}^{+}$cells/GCL, $P<0.001$ ). Although no neuroprotective efficacy was detected in excitotoxically lesioned OHSCs given MMF at $24\left(128.0 \mathrm{PI}^{+}\right.$cells/GCL), $36\left(138.8 \mathrm{PI}^{+}\right.$cells/GCL $)$or 48 hours $\left(153.6 \mathrm{PI}^{+}\right.$cells/GCL, $P>0.05$ ) (Figure $2 \mathrm{C}$ ) after injury, statistical analysis showed that the numbers of $\mathrm{IB}_{4}^{+}$microglial cells were consistently reduced $(24$ hours: 27.4 $\mathrm{IB}_{4}^{+}$cells/GCL; 36 hours: $27.7 \mathrm{IB}_{4}^{+}$cells/GCL; 48 hours: $40.2 \mathrm{IB}_{4}^{+}$cells/GCL, $P<0.001$ ) (Figure 2D) even after late initiation of MMF administration.

\section{Mycophenolate mofetil treatment in definite time windows after injury}

Treatment of OHSCs with MMF $100 \mu \mathrm{g} / \mathrm{ml}$ was performed in specific time-frames to determine the window of opportunity to achieve highest neuroprotective efficacy. When MMF treatment was scheduled in an early and short time window ( 4 to 8 hours after injury), there was no effect on either the number of $\mathrm{PI}^{+}$degenerating neurons or the number of $\mathrm{IB}_{4}^{+}$microglial cells in the DG compared with NMDA-lesioned OHSCs (4 to 8 hours: $143.8 \mathrm{PI}^{+}$and $46.5 \mathrm{IB}_{4}^{+}$cells/GCL, $P>0.05$ ) (Figure 3B, C). Administration of MMF during the window of 4 to 24 hours after injury also did not elicit neuroprotective effects on OHSCs (136.2 $\mathrm{PI}^{+}$cells/GCL, $\left.P>0.05\right)$ (Figure 3B), but significantly decreased the numbers of $\mathrm{IB}_{4}^{+}$microglial cells $\left(31.6 \mathrm{IB}_{4}^{+}\right.$cells/GCL, $\left.P<0.001\right)$ (Figure 3C).

However, application of MMF within a broader time window ( 4 to 48 hours after injury) significantly reduced the numbers of $\mathrm{PI}^{+}$neurons and $\mathrm{IB}_{4}^{+}$microglial cells (4 to 48 hours: $99.3 \mathrm{PI}^{+}$and $31.5 \mathrm{IB}_{4}^{+}$cells/GCL, $P<0.001$ ) (Figure 3B,C). Correspondingly, a delayed and shortened MMF treatment (12 to 36 hours after NMDA lesion) significantly reduced the numbers of $\mathrm{PI}^{+}$degenerating neurons and $\mathrm{IB}_{4}^{+}$microglial cells (12-36 hours: $105.8 \mathrm{PI}^{+}$ and $23.2 \mathrm{IB}_{4}^{+}$cells/GCL, $P<0.01$ ) (Figure $3 \mathrm{~B}, \mathrm{C}$ ). In subsequent experiments, this 12 to 36-hour time frame served as a positive control for highest MMF efficacy.

When MMF application was delayed to 24 hours after injury and lasted until 48 hours, the neuroprotective effects were lost, although administration within this late time window evenly reduced the mean numbers of microglial cells counted 72 hours after injury $\left(137.8 \mathrm{PI}^{+}\right.$ and $30.7 \mathrm{IB}_{4}^{+}$cells/GCL, $P<0.001$ ) (Figure $3 \mathrm{~B}, \mathrm{C}$ ).

\section{Antagonization of mycophenolate mofetil-induced purine depletion by pre-treatment with the nucleoside guanosine}

Application of guanosine $100 \mu \mathrm{mol} / \mathrm{l}$ on excitotoxically lesioned OHSCs that were subjected to MMF treatment was performed to investigate a possible antagonization of the MMF-induced neuroprotective and antiproliferative effects by refilling the previously depleted purine pools in glial cells.

Guanosine treatment on unlesioned control OHSCs did not affect neuronal survival or microglial cell numbers (control ${ }^{+}$guanosine: $0.4 \mathrm{PI}^{+}$cells/GCL, 6.4 $\mathrm{IB}_{4}^{+}$ cells/GCL, $P>0.05$ ) (Figure $3 \mathrm{D}, \mathrm{E}$ ), but it significantly reduced the degree of neuronal cell death when applied to NMDA-lesioned OHSCs (NMDA + guanosine: 97.4 $\mathrm{PI}^{+}$cells/GCL, $P<0.001$ ) (Figure $3 \mathrm{D}$ ) without affecting the number of $\mathrm{IB}_{4}^{+}$microglial cells $\left(57.2 \mathrm{IB}_{4}^{+}\right.$cells/GCL, $P>0.05$ ) (Figure 3E). When OHSCs subjected to MMF administration within the crucial neuroprotective 12 to 36-hour time window received guanosine pre-treatment, no changes in the neuroprotective efficacy of MMF were seen (MMF 12 to 36 hours + guanosine: $92.6 \mathrm{PI}^{+}$cells/ GCL, $P>0.05$ ) (Figure 3D). Similarly, there was no significant difference in the number of $\mathrm{PI}^{+}$degenerating neurons compared with lesioned OHSCs treated with guanosine alone $(P>0.05)$ (Figure $3 \mathrm{D})$. However, pretreatment with guanosine potently counteracted MMFmediated reductions in the number of microglial cells, 
as shown by significant increases in the number of $\mathrm{IB}_{4}^{+}$ microglial cells in GCL of DG (MMF 12 to 36 hours + guanosine: $43.1 \mathrm{IB}_{4}^{+}$cells/GCL, $P<0.001$ ) (Figure $3 \mathrm{E}$ ).

\section{Effects of mycophenolate mofetil on glial proliferation and apoptosis}

MMF treatment on NMDA-lesioned OHSCs within the crucial neuroprotective 12 to 36 -hour time window significantly reduced both microglial and astroglial proliferation indices assessed at 36 hours post-lesion (MMF 12 to 36 hours: $7.9 \% \mathrm{Ki}-67^{+}$microglial cells and $4.4 \%$ astrocytes, $P<0.001$ ) (Figure 4B,C). However, although MMF administration during the later time window of 24 to 48 hours after injury also significantly reduced the fraction of $\mathrm{Ki}-67^{+}$proliferating microglial cells, it did not alter the indices of astroglial proliferation assessed at 48 hours post-lesion (MMF 24 to 48 hours: $16.1 \% \mathrm{Ki}-67^{+}$ microglial cells, $P<0.01 ; 9.3 \%$ astrocytes, $P>0.05$ ) (Figure 4B,C).

Notably, treatment with MMF did not affect indices of either microglial or astroglial apoptosis when applied within the 12 to 36 -hours or 24 to 48 -hour time frames (MMF 12 to 36 hours: $5.7 \%$ caspase- $3^{+}$microglial cells and $2.3 \%$ astrocytes; MMF 24 to 48 hours: $10.5 \%$ caspase $-3^{+}$microglial cells and $5.3 \%$ astrocytes, $P>0.05$ ) (Figure 4E,F).

\section{Scratch-wound model: Effects of mycophenolate mofetil on astrocyte migration and proliferation}

To address the question of whether MMF can directly modulate astrogliosis, the in vitro scratch-wound model was used to determine the effects of MMF on mechanical injury-induced astrocyte proliferation. Ratios of Ki$67^{+}$reactive astrocytes around the wounded area were evaluated to determine scratch injury-induced astrocyte proliferation.

At 12 hours after scratching, the numbers of astrocytes within and next to the wound site had increased and the respective cytoplasmic processes extended to the denuded area. Cell proliferation adjacent to the wound site was significantly enhanced from 12 hours after the scratch procedure (12 hours: 41.3\%, 24 hours: 64.1\%, and 48 hours: $76.9 \% \mathrm{Ki}-67^{+}$proliferating astrocytes, $P<0.01$ ) (Figure 5A). Accordingly, high rates of proliferation led to a steady closing of the gap until cell density approached confluence at 48 hours post- scratching compared with control cultures at 0 hours $(P<0.001)$ (Figure 5B). Pre-treatment of astrocytes with MMF $1 \mu \mathrm{g} /$ $\mathrm{ml}$ significantly decreased the scratch injury-induced fraction of $\mathrm{Ki}-67^{+}$astrocytes at 24 and 48 hours compared with controls at the same time points (24 hours: $23.6 \%$ and 48 hours: $17.8 \%$, respectively, $P<0.001$ ) (Figure 5A). The reduced rates of proliferation after MMF treatment diminished the capacity of cell migration and glial scar formation as shown by the lack of gap closure $(P<0.001)$ (Figure $5 \mathrm{~B})$.

\section{Discussion}

In the aftermath of acute brain and spinal cord injuries, neuroinflammatory processes induce various cellular and molecular reactions, accompanied by rapid activation of both microglial cells and astrocytes. However, the mode and dimension of glial activation can even exacerbate the original extent of neuronal damage, with potentially harmful effects on neuronal survival, axonal regrowth, or restitution of complex network functions [41-43].

Based on this hypothesis, effective suppression of glial activation in a crucial time frame during the acute phase of pathophysiological responses would promote neuronal integrity. Several immunosuppressive substances possess the capacity to inhibit either microglial or astrocytic activation, resulting in significant neuroprotection in models of acute CNS lesion, as reviewed previously [44].

In previous studies, we have shown that treatment with the immunosuppressant MMF significantly reduces the extent of neuronal damage [30] and strongly promotes integrity of myelinated long-range projections when applied simultaneously with acute excitotoxic lesion induction [33]. The neuroprotective effects of MMF seemed to be indirectly mediated by counteraction of excessive cytokine secretion and proliferation of glial cells, which are hallmarks of secondary injury cascades [31].

Because clinically suitable drugs need to provide protection even if delivered hours after an incident (when patients can eventually be treated under clinical conditions), we analyzed in the present study the effects of MMF on NMDA-induced temporal patterns of glial proliferation and apoptosis, determined the time frame during which MMF elicits optimum neuroprotection, and investigated the role of MMF on glial scar formation. The well-established experimental model of OHSC was used, which enables analysis of neuron-glia interactions and temporal patterns of excitotoxic neuronal demise without the presence of confounding factors such as inflammatory cells infiltrating from the blood [45-47]. Microglial cells seem to be the only immunocompetent cell type in this model, as blood-borne monocytes and $\mathrm{T}$ lymphocytes are apparently absent [48]. Thus, OHSCs are suitable to analyze the effects of MMF on glial cells specifically in the context of neuroprotection.

Knowledge about the temporal patterns of glial proliferation and apoptosis after NMDA lesion is of crucial significance, as the excitotoxicity-mediated neuronal cell decline is generally accompanied by reactive glial cell recruitment and proliferation, and by activation of various apoptosis-related signal transduction pathways that in turn have the potential to exacerbate neuronal injury. 

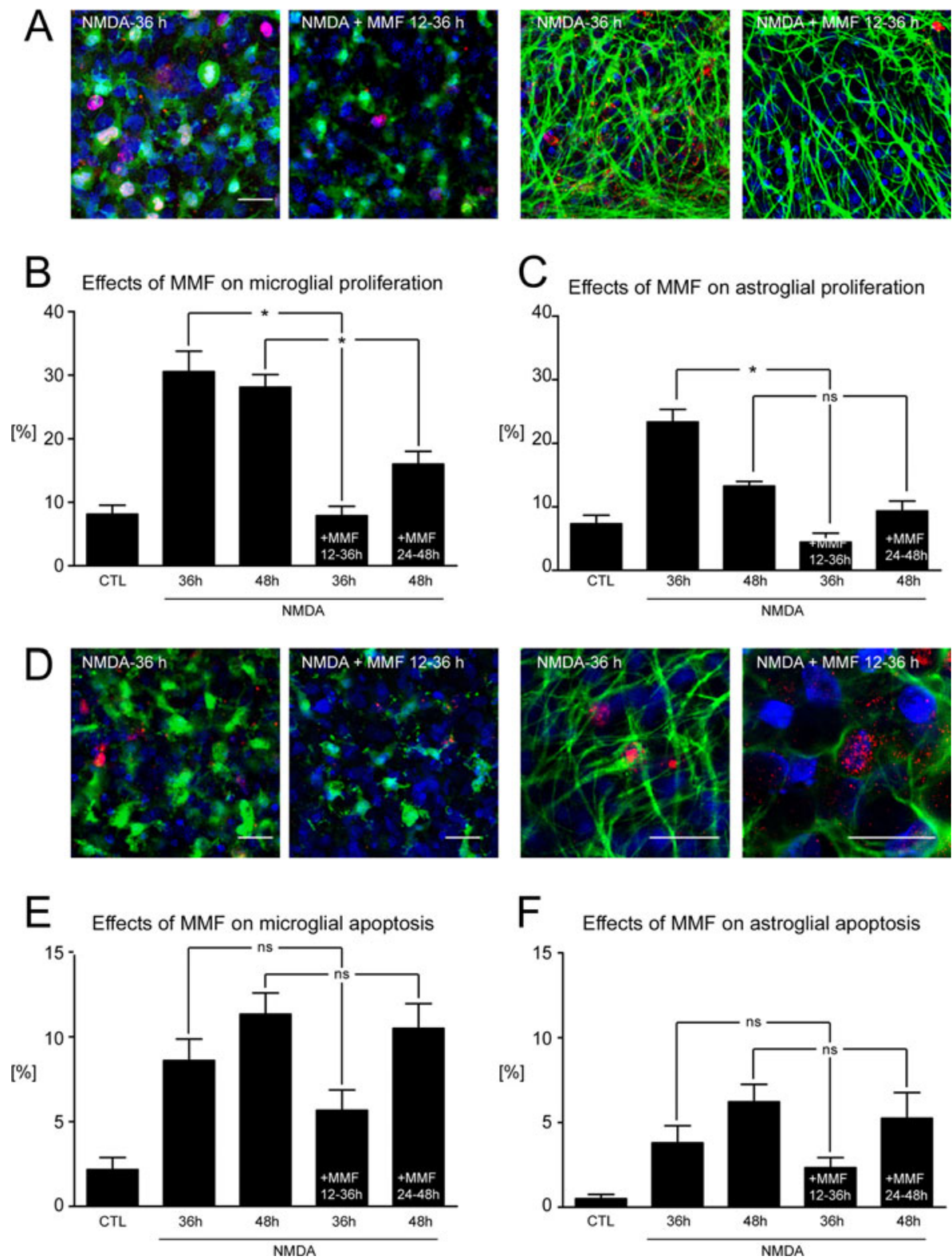

Figure 4 Effects of mycophenolate mofetil (MMF) treatment on glial apoptosis and proliferation. (A) High-magnification confocal laser scanning microscopy images, double-labeled with Ki-67 (proliferating cells, red) in combination with either isolectin (I)B $\mathrm{B}_{4}$ (microglial cells, green) or glial fibrillary acidic protein (astrocytes, green). Effects of MMF on (B) microglial and (C) astroglial proliferation indices at 36 hours or 48 hours post-lesion compared with lesioned organotypic hippocampal slice cultures (OHSCs) that received additional MMF treatment within 12 to 36 hours or 24 to 48 hours, respectively $(* P<0.05)$. (D) Confocal laser scanning microscopy images at high magnification, double-labeled with

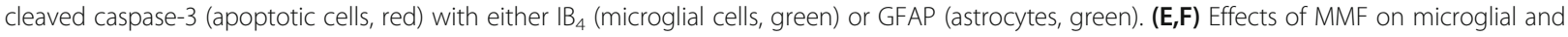
astroglial apoptosis indices at 36 or 48 hours post-lesion compared with lesioned OHSCs that received additional MMF treatment within 12-36 hours or 24 to 48 hours, respectively $\left({ }^{*} P<0.05\right)$. MMF treatment within the crucial neuroprotective $12-36$-hour time window potently attenuated microglial and astrocytic proliferation, but did not affect rates of glial apoptosis. Application of MMF within 24 to 48 hours post-lesion significantly reduced microglial proliferation but did not affect either astrocytic proliferation or glial apoptosis. Scale bars $=25 \mu \mathrm{m}$.

Exposure of OHSCs to NMDA after 6 days in vitro induced defined, quantifiable, and reproducible damage to granule cells of the DG, resulting in a pronounced increase in the number of proliferating astrocytes and microglial cells in the early phase after the induction of excitotoxic damage. The proliferation rates of microglial cells were increased to their highest level at 24 hours post-lesion but declined to control levels at 72 hours after injury. Comparably lower proliferation rates were found in astrocytes, although the ratios also increased 


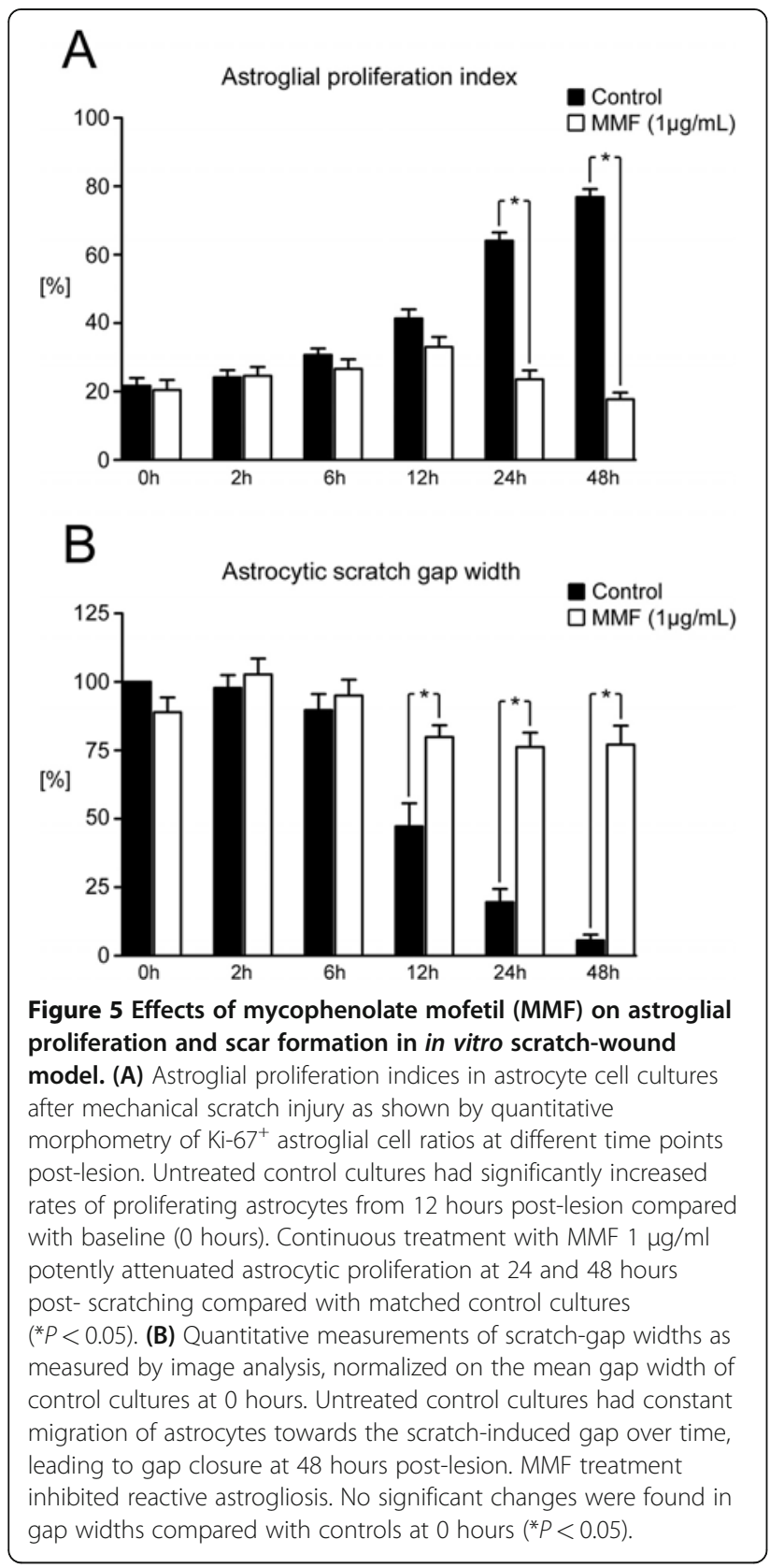

significantly from 12 to 36 hours post-lesion. These findings indicate that MMF treatment should be started within the first 12 hours after injury at the latest, and should be maintained until 36 hours after injury.

Although excitotoxin-induced neurodegeneration cannot be categorized as one singular mechanism of cell death, but rather involves a combination of necrotic, apoptotic, and autophagic processes [49], key features of apoptosis such as internucleosomal degradation, chromosome fragmentation, and activation of caspases are hallmarks of excitotoxic neuronal death [50,51]. In this regard, we found that in both microglial cells and astrocytes, apoptotic conditions were significantly augmented
24 hours post-lesion and remained increased until 72 hours post-lesion. Notably, quantities of the rate-limiting enzyme IMPDH2 were significantly diminished at 36 and 48 hours after NMDA application, which may be a counter-regulation to exorbitantly increased proliferation rates and might also account for the increased apoptosis indices. These findings emphasize the importance of schedule of administration in the neuroprotective efficacy of MMF.

In fact, delayed but continuous application of MMF on NMDA-lesioned OHSCs resulted in significant neuroprotection only when treatment was implemented at the latest at 12 hours post-lesion. The neuroprotective effects were most pronounced when MMF was applied earlier after the lesion at 4 hours or 8 hours after injury. Neuroprotective effects were paralleled by significant reductions in numbers of $\mathrm{IB}_{4}^{+}$microglial cells, thus suggesting that a main source of neuroprotection is a consequence of a potent inhibition of activated, proliferating and neurotoxic glial cells. Previous studies on the time course of excitotoxic neuronal injury after NMDA application showed that numbers of $\mathrm{PI}^{+}$neurons increase rapidly till 24 hours post-lesion and reach a plateau after 36 hours which persists until 72 hours post-lesion [52]. Therefore, late application of MMF will not significantly change the extent of neuronal demise but still be able to effectively suppress glial activation and proliferation.

To figure out the time of efficacy of MMF treatment, we performed a series of experiments with applications of MMF within defined time windows. The crucial time frame in which MMF application displayed the most potent inhibition of glial activation accompanied by significant neuroprotection was in between 12 hours till 36 hours after injury, being in accordance to the above described temporal patterns of neuronal demise. In further investigations on the effects of mycophenolate mofetil, this crucial time frame served as positive control of highest MMF efficacy.

To verify the hypothesis that inhibition of the enzyme IMPDH and subsequent depletion of the purine pool was responsible for the observed effects of MMF, the nucleoside guanosine was applied to refill the purine pools and consequently reverse the MMF-mediated effects. In previous studies, guanosine application was found to potently reverse the inhibitory effects of MMF on the proliferation of LPS-stimulated primary astrocytes and microglial cells [31]. In the current study, guanosine application to unlesioned control OHSCs after 6 days in vitro did not impair neuronal viability or numbers of microglial cells. However, guanosine treatment of NMDA-lesioned OHSCs resulted in significant neuroprotection without reductions in microglial cells, indicating direct neuroprotective effects on neurons. In fact, guanosine and guanine nucleotides have emerged as strongly neuroprotective agents that act by 
directly counteracting glutamate excitotoxicity [53]. Guanine nucleotides are thought to act as glutamate receptor antagonists [54] without affecting the binding capabilities of glutamate or its analogs to glutamate receptors $[55,56]$. Investigations into the molecular mechanisms underlying the neuroprotective activity indicate that guanosine promotes neuroprotection depending on $\mathrm{Ca}^{2+}$-activated $\mathrm{K}^{+}$ channels, G-protein-coupled receptors, and modulation of protein kinase (PK)A, PKC, mitogen-activated protein kinase, and phosphatidylinositol-3 kinase pathways in slices subjected to oxygen and glucose deprivation [57-61]. Accordingly, strong innate neuroprotective activity and the various pleiotropic effects of guanosine led to decreased numbers of degenerating neurons that could not further be reduced by MMF treatment. By contrast, application of guanosine to lesioned OHSCs subjected to MMF treatment potently antagonized the strong reductions in the numbers of microglial cells. These findings imply that the MMFmediated antiproliferative effects depend on depletion of purine metabolites as a consequence of IMPDH inhibition.

The apparent antagonization of MMF effects by substitution of purines should be distinguished from various independent guanosine-induced trophic responses on glial cells. Guanosine has been shown to stimulate proliferation of astrocytes $[62,63]$, and to induce the synthesis and release of neurotrophic and pleiotrophic factors by astrocytes and microglial cells $[64,65]$. Thus, the various pleiotropic effects described above make guanosine a very sophisticated candidate for the treatment of neuronal injury in vitro. However, the strongly hydrophilic nature of this compound will reduce its capability to enter the brain by passing the blood-brain-barrier in vivo.

To further investigate the cellular effects of MMF on astrocytes and microglial cells, proliferation and apoptosis assays and scratch-wound model experiments were performed. Treatment of NMDA-lesioned OHSCs with MMF significantly diminished the fraction of $\mathrm{Ki}-67^{+}$ proliferating glial cells when treatment was implemented within the crucial 12 to 36-hour neuroprotective time frame, confirming observations of previous studies on LPS-stimulated primary microglial cells and astrocytes [31]. Our present finding of reduced proliferation of microglial cells and astrocytes under the influence of MMF indicates that this substance exerts direct antiproliferative effects on both investigated glial cell types. In addition, MMF has been reported to inhibit the proliferation of various other cell types such as lymphocytes, fibroblasts, mesangial cells, and smooth muscle cells [66-69]. The antiproliferative effect of MMF seems to be based on arrest of the cell cycle in $\mathrm{S}$ phase, as was shown in human $\mathrm{T}$ cells and monocytes [70]. However, MMF treatment of NMDA-lesioned OHSCs within the crucial 12 to 36-hour time window did not promote or inhibit the initiation of apoptosis.

Similar effects were seen in the in vitro scratch-wound model of confluent astrocyte monolayers. The direct mechanical injury is generally accompanied by reactive astroglial scar formation along the lesion site. In confluent monolayers of astrocytes, injuries such as the scratch-induced mechanical break-up of cell-cell connections result in reactive astrocytic activation both in directly wounded cells and in larger cell populations in non-wounded areas throughout the culture. Consecutive signals are thought to spread through intercellular junctions [71] and by release of soluble factors such as cytokines or growth factors [72-74]. Activated astrocytes exhibit characteristic morphological signs of activation such as elongation of hypertrophic processes by realignment and expansion of the GFAPintermediate filament network or hypertrophy, being both essential for migratory and proliferative responses $[75,76]$.

After the scratch procedure, significant increases were seen in the rate of cell proliferation, predominantly within and around the wound from 12 hours after the scratching procedure until confluence was restored after 48 hours. Experimental groups treated with MMF had a significant decrease in the fraction of $\mathrm{Ki}-67^{+}$cells at 24 and 48 hours after scratching compared with control groups. Furthermore, the scratch-induced gap in these groups was not closed even at 48 hours post- scratching. These findings confirm the inhibitory effects of MMF on astrocyte proliferation, migration, and scar formation.

The modulatory and antiproliferative effects of MMF on microglial cells and astrocytes without direct effects on neurons strengthen the view that this immunosuppressive agent exerts its neuroprotective activity by inhibiting the potentially neurotoxic pro-inflammatory responses that are carried largely by microglia and astrocytes [31]. MMF has not been clinically used in the treatment of acute brain or spinal cord injury in humans to date, but there are reports on neurological benefits of this therapy in various chronic neurological disorders. MMF has been used in the treatment of refractory multiple sclerosis [77,78], multifocal motor neuropathy [79] and chronic inflammatory polyneuropathy [80]. Against the background of strongly beneficial effects on neuronal survival and recovery in numerous in vitro studies in combination with promising clinical observations, MMF might be a future candidate for the treatment of acute CNS injuries in humans.

However, despite its broad immunosuppressive abilities making MMF an efficacious drug for transplant and autoimmune diseases, the conceivable risk of infectious complications should be considered. Recipients of solid-organ transplants who receive MMF as part of their post-transplant immunosuppressive regimen seem to have increased susceptibility to infections $[81,82]$ especially cytomegalovirus [83]. However, infectious complications are 
seen predominantly more than 1 month after initiation of MMF treatment, thus an association with post-transplant renal insufficiency was assumed [84].

In contrast to the long-term applications of MMF, our results indicate that use of MMF as a pharmacological intervention after excitotoxic injury is required only within the first days after injury, thus the risk of postlesion infections is likely to be low. Nevertheless, in vivo experiments are needed to clarify the short-term risks of MMF treatment.

\section{Conclusions}

Taken together, our findings emphasize the therapeutic potential of MMF after acute excitotoxic brain injury. Our results indicate that: 1) delayed administration of MMF until 12 hours after injury potently reduces the extent of secondary neuronal damage; 2) MMF application within the crucial 12 to 36 -hour time frame most effectively repealed neuroinflammatory responses and resulted in significant neuroprotection; 3) the neuroprotective agent guanosine antagonized the inhibitory effects of MMF on glial cell activation; 4) MMF effectively suppressed both microglial and astroglial proliferation; 5) apoptosis of glial cells in the aftermath of excitotoxicity was not affected by MMF, and 6) MMF potently counteracted reactive astrogliosis in vitro.

These findings emphasize the potential of MMF as a promising and valuable therapeutic candidate in conditions such as cerebral ischemia, spinal cord injury, or trauma.

\footnotetext{
Abbreviations

CNS: Central nervous system; DAPI: 4'-6-diamidino-2-phenlyindole; DG: Dentate gyrus; DMEM: Dulbecco's modified Eagle's medium; FCS: fetal calf serum; GFAP: Glial fibrillary acidic protein; GCL: granule cell layer; $\mathrm{IB}_{4}$ : isolectin $\mathrm{B}_{4}$; IMPDH: Inosine 5-monophosphate dehydrogenase; LPS: Lipopolysaccharide; MEM: Minimal essential medium; MMF: Mycophenolate mofetil; NMDA: N-methyl-D-aspartate; OHSC: Organotypic hippocampal slice culture; PBS: phosphate-buffered saline; PI: Propidium iodide; PK: protein kinase; SDS-PAGE: sodium dodecyl sulfate polyacrylamide gel electrophoresis.
}

\section{Competing interests}

The authors have no competing interests to disclose.

\section{Acknowledgements}

We thank Angela Ehrlich and Dana Tschierske for their excellent technical assistance. This study was partly supported by the DFG (FOR 1336) and BMBF (Tierversuch-Ersatzmethoden).

\section{Authors' contributions}

$F E, C G, P P$, and $C H$ performed the experiments. FD designed and coordinated the experiments. FE, MK, IB, and FD analyzed the data and wrote the manuscript. All authors have read and approved the final version of this manuscript.

Received: 6 January 2012 Accepted: 8 May 2012

Published: 8 May 2012

\section{References}

1. Giulian D, Robertson C: Inhibition of mononuclear phagocytes reduces ischemic injury in the spinal cord. Ann Neurol 1990, 27:33-42.
2. Dusart I, Schwab ME: Secondary cell death and the inflammatory reaction after dorsal hemisection of the rat spinal cord. Eur J Neurosci 1994, 6:712-724.

3. Bartholdi D, Schwab ME: Expression of pro-inflammatory cytokine and chemokine mRNA upon experimental spinal cord injury in mouse: an in situ hybridization study. Eur J Neurosci 1997, 9:1422-1438.

4. Dumont RJ, Okonkwo DO, Verma S, Hurlbert RJ, Boulos PT, Ellegala DB, Dumont AS: Acute spinal cord injury, part I: pathophysiologic mechanisms. Clin Neuropharmacol 2001, 24:254-264.

5. Horn K, Busch S, Hawthorne A, Van R, Silver J: Another barrier to regeneration in the CNS: activated macrophages induce extensive retraction of dystrophic axons through direct physical interactions. J Neurosci 2008, 28:9330-9341.

6. Popovich PG, Guan Z, Wei P, Huitinga I, Van R, Stokes BT: Depletion of hematogenous macrophages promotes partial hindlimb recovery and neuroanatomical repair after experimental spinal cord injury. Exp Neurol 1999, 158:351-365.

7. Kitayama M, Ueno M, Itakura T, Yamashita T: Activated microglia inhibit axonal growth through RGMa. PLoS One 2011, 6:e25234.

8. Murai K, Pasquale E: Eph receptors and ephrins in neuron-astrocyte communication at synapses. Glia 2011, 59:1567-1578.

9. Boje KM, Arora PK: Microglial-produced nitric oxide and reactive nitrogen oxides mediate neuronal cell death. Brain Res 1992, 587:250-256.

10. Rinner WA, Bauer J, Schmidts M, Lassmann H, Hickey WF: Resident microglia and hematogenous macrophages as phagocytes in adoptively transferred experimental autoimmune encephalomyelitis: an investigation using rat radiation bone marrow chimeras. Glia 1995, 14:257-266.

11. Flavin MP, Coughlin K, Ho LT: Soluble macrophage factors trigger apoptosis in cultured hippocampal neurons. Neuroscience 1997, 80:437-448.

12. Kim WK, Ko KH: Potentiation of N-methyl-D-aspartate-mediated neurotoxicity by immunostimulated murine microglia. J Neurosci Res 1998, 54:17-26.

13. Frade JM, Barde YA: Microglia-derived nerve growth factor causes cell death in the developing retina. Neuron 1998, 20:35-41.

14. Hailer NP, Wirjatijasa F, Roser N, Hischebeth GT, Korf HW, Dehghani F: Astrocytic factors protect neuronal integrity and reduce microglial activation in an in vitro model of $\mathrm{N}$-methyl-D-aspartate-induced excitotoxic injury in organotypic hippocampal slice cultures. Eur J Neurosci 2001, 14:315-326.

15. Toulmond S, Rothwell NJ: Interleukin-1 receptor antagonist inhibits neuronal damage caused by fluid percussion injury in the rat. Brain Res 1995, 671:261-266.

16. Wakita $\mathrm{H}$, Tomimoto $\mathrm{H}$, Akiguchi I, Kimura J: Protective effect of cyclosporin $\mathrm{A}$ on white matter changes in the rat brain after chronic cerebral hypoperfusion. Stroke 1995, 26:1415-1422.

17. Zito MA, Koennecke LA, McAuliffe MJ, McNally B, van Rooijen N, Heyes MP Depletion of systemic macrophages by liposome-encapsulated clodronate attenuates striatal macrophage invasion and neurodegeneration following local endotoxin infusion in gerbils. Brain Res 2001, 892:13-26.

18. Bracken MB, Shepard MJ, Holford TR, Leo-Summers L, Aldrich EF, Fazl M, Fehlings MG, Herr DL, Hitchon PW, Marshall LF, Nockels RP, Pascale V, Perot PL, Piepmeier J, Sonntag VK, Wagner F, Wilberger JE, Winn HR, Young W: Methylprednisolone or tirilazad mesylate administration after acute spinal cord injury: 1-year follow up. Results of the third National Acute Spinal Cord Injury randomized controlled trial. J Neurosurg 1998, 89:699-706

19. Takami T, Oudega M, Bethea JR, Wood PM, Kleitman N, Bunge MB: Methylprednisolone and interleukin-10 reduce gray matter damage in the contused Fischer rat thoracic spinal cord but do not improve functional outcome. J Neurotrauma 2002, 19:653-666.

20. Hurlbert RJ: Strategies of medical intervention in the management of acute spinal cord injury. Spine 2006, 31:16-21. discussion S36.

21. Teichner A, Morselli E, Buttarelli FR, Caronti B, Pontieri FE, Venturini G, Palladini G: Treatment with cyclosporine A promotes axonal regeneration in rats submitted to transverse section of the spinal cord. J Hirnforsch 1993, 34:343-349.

22. Madsen JR, MacDonald P, Irwin N, Goldberg DE, Yao GL, Meiri KF, Rimm IJ, Stieg PE, Benowitz LI: Tacrolimus (FK506) increases neuronal expression 
of GAP-43 and improves functional recovery after spinal cord injury in rats. Exp Neurol 1998, 154:673-683.

23. Bavetta S, Hamlyn PJ, Burnstock G, Lieberman AR, Anderson PN: The effects of FK506 on dorsal column axons following spinal cord injury in adult rats: neuroprotection and local regeneration. Exp Neurol 1999, 158:382-393.

24. Klettner A, Herdegen T: FK506 and its analogs - therapeutic potential for neurological disorders. Curr Drug Targets CNS Neurol Disord 2003, 2:153-162.

25. Halloran P, Mathew T, Tomlanovich S, Groth C, Hooftman L, Barker C: Mycophenolate mofetil in renal allograft recipients: a pooled efficacy analysis of three randomized, double-blind, clinical studies in prevention of rejection. The International Mycophenolate Mofetil Renal Transplant Study Groups. Transplantation 1997, 63:39-47.

26. Eugui EM, Mirkovich A, Allison AC: Lymphocyte-selective antiproliferative and immunosuppressive effects of mycophenolic acid in mice. Scand J Immunol 1991, 33:175-183.

27. Allison AC, Eugui EM: Mycophenolate mofetil and its mechanisms of action. Immunopharmacology 2000, 47:85-118.

28. Villarroel MC, Hidalgo M, Jimeno A: Mycophenolate mofetil: An update. Drugs Today 2009, 45:521-532.

29. Carr SF, Papp E, Wu JC, Natsumeda Y: Characterization of human type I and type II IMP dehydrogenases. J Biol Chem 1993, 268:27286-27290.

30. Dehghani F, Hischebeth GTR, Wirjatijasa F, Kohl A, Korf H, Hailer NP: The immunosuppressant mycophenolate mofetil attenuates neuronal damage after excitotoxic injury in hippocampal slice cultures. Eur J Neurosci 2003, 18:1061-1072.

31. Dehghani F, Sayan M, Conrad A, Evers J, Ghadban C, Blaheta R, Korf H, Hailer NP: Inhibition of microglial and astrocytic inflammatory responses by the immunosuppressant mycophenolate mofetil. Neuropathol Appl Neurobiol 2010, 36:598-611.

32. Miljkovic D, Cvetkovic I, Stosic-Grujicic S, Trajkovic V: Mycophenolic acid inhibits activation of inducible nitric oxide synthase in rodent fibroblasts. Clin Exp Immunol 2003, 132:239-246.

33. Oest TM, Dehghani F, Korf $H$, Hailer NP: The immunosuppressant mycophenolate mofetil improves preservation of the perforant path in organotypic hippocampal slice cultures: a retrograde tracing study. Hippocampus 2006, 16:437-442.

34. Cottrell BL, Perez-Abadia G, Onifer SM, Magnuson DS, Burke DA, Grossi FV, Francois $\mathrm{CG}$, Barker $\mathrm{JH}$, Maldonado C: Neuroregeneration in composite tissue allografts: effect of low-dose FK506 and mycophenolate mofetil immunotherapy. Plast Reconstr Surg 2006, 118:615-623. discussion 624-5.

35. Stoppini L, Buchs PA, Muller D: A simple method for organotypic cultures of nervous tissue. J Neurosci Methods 1991, 37:173-182.

36. Pozzo MLD, Mahanty NK, Connor JA, Landis DM: Spontaneous pyramidal cell death in organotypic slice cultures from rat hippocampus is prevented by glutamate receptor antagonists. Neuroscience 1994, 63:471-487.

37. Ebrahimi F, Hezel M, Koch M, Ghadban C, Korf H, Dehghani F: Analyses of neuronal damage in excitotoxically lesioned organotypic hippocampal slice cultures. Ann Anat 2010, 192:199-204.

38. Kohl A, Dehghani F, Korf H, Hailer NP: The bisphosphonate clodronate depletes microglial cells in excitotoxically injured organotypic hippocampal slice cultures. Exp Neurol 2003, 181:1-11.

39. Bradford MM: A rapid and sensitive method for the quantitation of microgram quantities of protein utilizing the principle of protein-dye binding. Anal Biochem 1976, 72:248-254.

40. Dehghani F, Conrad A, Kohl A, Korf H, Hailer NP: Clodronate inhibits the secretion of proinflammatory cytokines and NO by isolated microglial cells and reduces the number of proliferating glial cells in excitotoxically injured organotypic hippocampal slice cultures. Exp Neurol 2004, 189:241-251.

41. Vijayan VK, Cotman CW: Hydrocortisone administration alters glial reaction to entorhinal lesion in the rat dentate gyrus. Exp Neurol 1987, 96:307-320

42. Kitamura Y, Itano Y, Kubo T, Nomura Y: Suppressive effect of FK-506, a novel immunosuppressant, against MPTP-induced dopamine depletion in the striatum of young C57BL/6 mice. J Neuroimmunol 1994, 50:221-224

43. Oudega M, Vargas CG, Weber AB, Kleitman N, Bunge MB: Long-term effects of methylprednisolone following transection of adult rat spinal cord. Eur J Neurosci 1999, 11:2453-2464.
44. Hailer NP: Immunosuppression after traumatic or ischemic CNS damage: it is neuroprotective and illuminates the role of microglial cells. Prog Neurobiol 2008, 84:211-233.

45. Adamchik Y, Frantseva MV, Weisspapir M, Carlen PL, Perez Velazquez JL: Methods to induce primary and secondary traumatic damage in organotypic hippocampal slice cultures. Brain Res Brain Res Protoc 2000, 5:153-158.

46. Hailer NP, Vogt C, Korf H, Dehghani F: Interleukin-1 beta exacerbates and interleukin-1 receptor antagonist attenuates neuronal injury and microglial activation after excitotoxic damage in organotypic hippocampal slice cultures. Eur J Neurosci 2005, 21:2347-2360.

47. Kreutz S, Koch M, Böttger C, Ghadban C, Korf H, Dehghani F: 2Arachidonoylglycerol elicits neuroprotective effects on excitotoxically lesioned dentate gyrus granule cells via abnormal-cannabidiol-sensitive receptors on microglial cells. Glia 2009, 57:286-294.

48. Hailer NP, Jarhult JD, Nitsch R: Resting microglial cells in vitro: analysis of morphology and adhesion molecule expression in organotypic hippocampal slice cultures. Glia 1996, 18:319-331.

49. Martin LJ, Al-Abdulla NA, Brambrink AM, Kirsch JR, Sieber FE, Portera-Cailliau C: Neurodegeneration in excitotoxicity, global cerebral ischemia, and target deprivation: A perspective on the contributions of apoptosis and necrosis. Brain Res Bull 1998, 46:281-309.

50. Qin ZH, Wang Y, Chase TN: Stimulation of N-methyl-D-aspartate receptors induces apoptosis in rat brain. Brain Res 1996, 725:166-176.

51. Pohl D, Bittigau P, Ishimaru MJ, Stadthaus D, Hubner C, Olney JW, Turski L, Ikonomidou C: N-Methyl-D-aspartate antagonists and apoptotic cell death triggered by head trauma in developing rat brain. Proc Natl Acad Sci U S A 1999, 96:2508-2513.

52. Vogt C, Hailer NP, Ghadban C, Korf H, Dehghani F: Successful inhibition of excitotoxic neuronal damage and microglial activation after delayed application of interleukin-1 receptor antagonist. J Neurosci Res 2008, 86:3314-3321.

53. Schmidt AP, Lara DR, Souza DO: Proposal of a guanine-based purinergic system in the mammalian central nervous system. Pharmacol Ther 2007, 116:401-416.

54. Baron BM, Dudley MW, McCarty DR, Miller FP, Reynolds IJ, Schmidt CJ: Guanine nucleotides are competitive inhibitors of N-methyl-D-aspartate at its receptor site both in vitro and in vivo. J Pharmacol Exp Ther 1989, 250:162-169.

55. Porciuncula LO, Vinade L, Wofchuk S, Souza DO: Guanine based purines inhibit glutamate and AMPA binding at postsynaptic densities from cerebral cortex of rats. Brain Res 2002, 928:106-112.

56. Souza DO, Ramirez G: Effects of guanine nucleotides on kainic acid binding and on adenylate cyclase in chick optic tectum and cerebellum. J Mol Neurosci 1991, 3:39-45.

57. Dal-Cim T, Martins WC, Santos AR, Tasca Cl: Guanosine is neuroprotective against oxygen/glucose deprivation in hippocampal slices via large conductance $\mathrm{Ca}(2+)$-activated $\mathrm{K}(+)$ channels, phosphatidilinositol-3 kinase/protein kinase B pathway activation and glutamate uptake. Neuroscience 2011, 183:212-220

58. Molz S, Dal-Cim T, Budni J, Martín-de-Saavedra M, Egea J, Romero A, del Barrio L, Rodrigues AL, López MG, Tasca Cl: Neuroprotective effect of guanosine against glutamate-induced cell death in rat hippocampal slices is mediated by the phosphatidylinositol-3 kinase/Akt/glycogen synthase kinase $3 \beta$ pathway activation and inducible nitric oxide synthase inhibition. J Neurosci Res 2011, 89:1400-1408.

59. Oleskovicz SPB, Martins WC, Leal RB, Tasca Cl: Mechanism of guanosine-induced neuroprotection in rat hippocampal slices submitted to oxygen-glucose deprivation. Neurochem Int 2008, 52:411-418.

60. Benfenati V, Caprini M, Nobile M, Rapisarda C, Ferroni S: Guanosine promotes the up-regulation of inward rectifier potassium current mediated by Kir4.1 in cultured rat cortical astrocytes. J Neurochem 2006, 98:430-445.

61. Volpini R, Marucci G, Buccioni M, Dal Ben D, Lambertucci C, Lammi C, Mishra RC, Thomas A, Cristalli G: Evidence for the Existence of a Specific G Protein-Coupled Receptor Activated by Guanosine. Chem. Med. Chem 2011, 6:1074-1080

62. Kim JK, Rathbone MP, Middlemiss PJ, Hughes DW, Smith RW: Purinergic stimulation of astroblast proliferation: guanosine and its nucleotides stimulate cell division in chick astroblasts. J Neurosci Res 1991, 28:442-455. 
63. Ciccarelli R, Di lorio P, Giuliani P, D'Alimonte I, Ballerini P, Caciagli F, Rathbone MP: Rat cultured astrocytes release guanine-based purines in basal conditions and after hypoxia/hypoglycemia. Glia 1999, 25:93-98.

64. Middlemiss PJ, Gysbers JW, Rathbone MP: Extracellular guanosine and guanosine-5'-triphosphate increase: NGF synthesis and release from cultured mouse neopallial astrocytes. Brain Res 1995, 677:152-156.

65. Di lorio P, Kleywegt S, Ciccarelli R, Traversa U, Andrew CM, Crocker CE, Werstiuk ES, Rathbone MP: Mechanisms of apoptosis induced by purine nucleosides in astrocytes. Glia 2002, 38:179-190.

66. Heinz C: Mycophenolate mofetil inhibits human Tenon fibroblast proliferation by guanosine depletion. Br J Ophthalmol 2003, 87:1397-1398.

67. Raisanen-Sokolowski A, Vuoristo P, Myllarniemi M, Yilmaz S, Kallio E, Hayry P: Mycophenolate mofetil (MMF, RS-61443) inhibits inflammation and smooth muscle cell proliferation in rat aortic allografts. Transpl Immunol 1995, 3:342-351.

68. Waller J, Brook NR, Nicholson ML: Cardiac allograft vasculopathy: current concepts and treatment. Transplant. Int 2003, 16:367-375.

69. Ziswiler R, Steinmann-Niggli K, Kappeler A, Daniel C, Marti HP: Mycophenolic acid: a new approach to the therapy of experimental mesangial proliferative glomerulonephritis. J Am Soc Nephrol 1998, 9:2055-2066.

70. Cohn RG, Mirkovich A, Dunlap B, Burton P, Chiu SH, Eugui E, Caulfield JP: Mycophenolic acid increases apoptosis, lysosomes and lipid droplets in human lymphoid and monocytic cell lines. Transplantation 1999, 68:411-418.

71. Lin JH, Weigel H, Cotrina ML, Liu S, Bueno E, Hansen AJ, Hansen TW, Goldman S, Nedergaard M: Gap-junction-mediated propagation and amplification of cell injury. Nat Neurosci 1998, 1:494-500

72. Faber-Elman A, Lavie V, Schvartz I, Shaltiel S, Schwartz M: Vitronectin overrides a negative effect of TNF-alpha on astrocyte migration. FASEB $J$ 1995, 9:1605-1613.

73. Hou YJ, Yu AC, Garcia JM, Aotaki-Keen A, Lee YL, Eng LF, Hjelmeland L, Menon VK: Astrogliosis in culture. IV. Effects of basic fibroblast growth factor. J Neurosci Res 1995, 40:359-370.

74. Hassinger TD, Guthrie PB, Atkinson PB, Bennett MV, Kater SB: An extracellular signaling component in propagation of astrocytic calcium waves. Proc Natl Acad Sci U S A 1996, 93:13268-13273.

75. Yu ACH, Lee Y, Eng LF: Astrogliosis in culture: I. The model and the effect of antisense oligonucleotides on glial fibrillary acidic protein synthesis. J Neurosci Res 1993, 34:295-303.

76. Toyooka T, Nawashiro H, Shinomiya N, Shima K: Down-regulation of glial fibrillary acidic protein and vimentin by RNA interference improves acute urinary dysfunction associated with spinal cord injury in rats. $J$ Neurotrauma 2011, 28:607-618.

77. Ahrens N, Salama A, Haas J: Mycophenolate-mofetil in the treatment of refractory multiple sclerosis. J Neurol 2001, 248:713-714

78. Frohman EM, Brannon K, Racke MK, Hawker K: Mycophenolate mofetil in multiple sclerosis. Clin Neuropharmacol 2004, 27:80-83.

79. Piepers S, van den Berg-Vos R, van der Pol W, Franssen H, Wokke J, van den Berg L: Mycophenolate mofetil as adjunctive therapy for MMN patients: a randomized, controlled trial. Brain 2007, 130:2004-2010.

80. Mowzoon N, Sussman A, Bradley WG: Mycophenolate (CellCept) treatment of myasthenia gravis, chronic inflammatory polyneuropathy and inclusion body myositis. J Neurol Sci 2001, 185:119-122.

81. Pourmand G, Salem S, Mehrsai A, Taherimahmoudi M, Ebrahimi R, Pourmand MR: Infectious complications after kidney transplantation: a single-center experience. Transpl Infect Dis 2007, 9:302-309.

82. Pourfarziani V, Panahi Y, Assari S, Moghani-Lankarani M, Saadat S: Changing treatment protocol from azathioprine to mycophenolate mofetil: decrease in renal dysfunction, increase in infections. Transplant Proc 2007, 39:1237-1240

83. Sollinger HW: Mycophenolate mofetil for the prevention of acute rejection in primary cadaveric renal allograft recipients. U.S. Renal Transplant Mycophenolate Mofetil Study Group. Transplantation 1995, 60:225-232.

84. Hanvesakul R, Kubal C, Jham S, Sarkar E, Eardley K, Adu D, Cockwell P: Increased incidence of infections following the late introduction of mycophenolate mofetil in renal transplant recipients. Nephrol Dial Transplant 2008, 23:4049-4053. doi:10.1186/1742-2094-9-89

Cite this article as: Ebrahimi et al:: Time dependent neuroprotection of mycophenolate mofetil: effects on temporal dynamics in glial proliferation, apoptosis, and scar formation. Journal of Neuroinflammation 2012 9:89.

\section{Submit your next manuscript to BioMed Central and take full advantage of:}

- Convenient online submission

- Thorough peer review

- No space constraints or color figure charges

- Immediate publication on acceptance

- Inclusion in PubMed, CAS, Scopus and Google Scholar

- Research which is freely available for redistribution 